\title{
EDUCATIONAL OR SCIENTIFIC CAREER?
}

\author{
Svetlana V. Lezhenina ${ }^{1}$, Nadezhda V. Shuvalova ${ }^{2}$, Ansell Lammert ${ }^{3^{*}}$ \\ Venera P. Akimova ${ }^{4}$, Marina N. Grigorieva ${ }^{5}$, Roman S. Matveev ${ }^{6}$, \\ Mikchail O. Basov ${ }^{7}$, Alla S. Pavlovskaya ${ }^{8}$
}

${ }^{1}$ Assoc. Prof., M.D., Ph.D., I. N. Ulyanov Chuvash State University, RUSSIA, svl-8888@bk.ru

${ }^{2}$ Prof, M.D., D.Sc., I. Ya. Yakovlev Chuvash State Pedagogical University, RUSSIA, msta77@yandex.ru

${ }^{3}$ M.D., M.Sc., B.Sc.N., I. N. Ulyanov Chuvash State University, RUSSIA, anselllammert@seznam.cz

${ }^{4}$ Assoc. Prof., M.D., Ph.D., I. N. Ulyanov Chuvash State University, RUSSIA, anselllammert@gmail.com

${ }^{5}$ Assoc. Prof., M.D., Ph.D., I. N. Ulyanov Chuvash State University, RUSSIA, dimapotapov20@gmail.com

${ }^{6}$ Prof, M.D., D.Sc., Institute for Postgraduate Medical Education, RUSSIA, sjuri71@gmail.com

${ }^{7}$ Assoc. Prof., M.D., Ph.D., Institute for Postgraduate Medical Education, RUSSIA, svl-888@bk.ru ${ }^{8}$ Student, I. N. Ulyanov Chuvash State University, RUSSIA, all5049@yandex.ru

${ }^{*}$ Corresponding Author

\begin{abstract}
One problem with teaching higher educational institutions by university professors is that the educator spends most of the time on their own scientific activities to the detriment of the pedagogical orientation of the learning process and methodology. In addition, the requirements for research and publication activity are constantly increasing, and we often encounter the concentration of teachers' attention on a scientific orientation. As a result these teachers sometimes neglect the very process of teaching students, which leads to the loss of the importance of the pedagogical component of the educational process. The overall nature of the problem lies in the importance of teaching in universities, where teaching is considered a priority activity comparable to science and research. Therefore, in our environment, we can observe a gradually increasing offer of programs to strengthen the pedagogical competencies of teachers. In this article, we decided to focus on the pedagogical component of the educational process of teachers of higher educational institutions of the Chuvash Republic and their participation in the educational program.
\end{abstract}

Purpose of the study: analyze how university teachers perceive and evaluate their pedagogical competencies, that is, how university teachers perceive themselves as a teacher and at the same time how they evaluate professional development programs that are focused on systematic improvement of the level of pedagogical competencies. The research problem lies in the dilemma between the pedagogical development of university teachers (participation in professional development programs) and the concentration on the research component of teaching.

The central point of this entire study is the perception of their own pedagogical development by the university teachers themselves and the assessment of the quality of professional development programs. We chose to conduct detailed interviews with 25 teachers from the Chuvash State University of the Chuvash Republic as the central method for data collection.

The respondents perceive other university professors not only as scientific experts in their discipline, but also as teachers capable of providing high-quality teaching. At the same time, none of the respondents called 
themselves a scientific expert in their field. All respondents would like to reduce the scientific component in their pedagogical work, leaving it for some specialized scientific centers. Also, all respondents would like to pay more attention to the very pedagogical process of teaching students - transferring knowledge, communicating with students or teaching students logical thinking, and forming high-quality professional competencies in their pupils. They also pointed out that attempting to save time in the learning process of students forms a "time bomb", which will further negatively affect the socio-cultural development of society. Most of the respondents believe that the best way to develop their pedagogical competencies is to regularly communicate with their mentors - more professionally competent people. They do not believe that the use of advanced training programs is so important.

Keywords: pedagogical competence of university teachers, scientific activity of university teachers, advanced training of university teachers.

\section{NTRODUCTION}

In recent years, there has been a significant increase in the number of teachers who have decided to take up research work, which also contributes to their career growth. Of course, while this criterion is still relatively small in the system of advanced training, but still there is a noticeable increase in the number of teachers who want to form their own competencies through research (Legostaeva, 2009, pp. 33-37; Maralova, 2013, pp. 73-80).

Each person has a career choice. Someone decides not to "conquer" the career ladder and work for their own pleasure, and someone by any means tries to advance in the position. To do this, you need to plan your activities, and then your own scientific and pedagogical career will become manageable.

One of the problems associated with teaching in higher educational institutions by university professors is that the teacher spends most of his time on his own scientific activities to the detriment of the pedagogical orientation of the educational process and methodology. In addition, the requirements for research and publication activity are constantly growing, and we often encounter the concentration of teachers' attention on the scientific direction. As a result, these teachers sometimes neglect the very process of teaching students, which leads to the loss of the importance of the pedagogical component of the educational process (Pan'kova, 2013, pp. 4-13).

Today's teaching career requires special attention. The developing community does not care who will work as a teacher: an impassive performer or a professional striving to reveal his own creative potential to a greater extent (Reznik, Makarova, 2010; Nikolaev, 2012). This dictates the need for research and implementation in the educational sphere of concepts, programs and models for building a career of the teaching staff, which are aimed at helping, supporting, encouraging and applying all the real skills of career growth (Reznik, 2011, pp. 49-54).

If we consider the career growth of a teacher as a dynamic process, then it should be noted that it is directly related to professional growth, as well as the readiness of the individual for self-development and selfimprovement within the framework of their own professional activities (Reznik, 2010, pp. 70-76).

The main thing in professional growth is the teacher himself, as well as his expectations, ideas about his working future - the future as a teacher or researcher.

The general nature of the problem is the importance of teaching in universities, where teaching is considered a priority activity, comparable to science and research. Therefore, in our pedagogical environment, we can observe a gradually increasing offer of programs to strengthen the pedagogical competencies of teachers, as well as increasing requirements for the scientific component of the pedagogical process (Reznik, Vdovina, 2013).

In this article, we decided to focus on the pedagogical and scientific component of the educational process of teachers of the Chuvash State University and evaluate their participation in educational programs (advanced training programs).

\section{OBJECTIVE OF THE STUDY}

Analyze how Chuvash University teachers perceive and evaluate their pedagogical competencies, that is, how teachers perceive themselves as a teacher and a researcher, and at the same time, how they evaluate 
professional development programs aimed at systematically increasing the level of pedagogical competencies in the career and growth structure.

\section{METHODOLOGY}

The central point of this entire study is the perception of university teachers of their own pedagogical development and the assessment of the quality of advanced training programs. As the main method of data collection, we chose a detailed interview with 25 teachers of the Chuvash State University of the Chuvash Republic. The respondents were 25 University professors, of whom 15 were women and 10 were men. The average age of the respondents was $65 \pm 3.2$ years.

In the structure of the questionnaires, the following questions were posed: 1) Does the personnel department of the University deal with planning the career of teachers? (that is, the personal profile for the teaching staff has or does not have a continuing education trajectory for teachers (calendar of professional development for the teacher). 2) Does the training program contribute to the development of teacher's pedagogical competencies? 3) Did they expect during their postgraduate studies that they will engage in scientific and pedagogical activities in the volume in which they are currently engaged? 4) What prevents teachers from engaging in scientific activities. 5) Are you satisfied with your teaching work? 6) What do you consider important to advance your career. 7) What motivated you to choose scientific and pedagogical activity.

\section{RESULTS AND THEIR DISCUSSION}

During the analysis, it was noted that $35 \%$ do not know the answer to the question "Does the University HR department do career planning for teachers?", 53\% believe that the HR department is not involved in teacher career planning, and only $12 \%$ answered the question positively.

We believe that the results obtained indicate the problem of structuring the activities of teachers within the walls of the University. It is more difficult for teachers to keep track of constantly changing training programs to expand the competencies of teachers, the number of which is constantly increasing. Teachers are not able to keep track of and keep abreast of these programs, in view of their pedagogical and scientific workload.

On this issue, the following conclusion can be drawn - the University Human Resources Department should independently organize the planning of continuing education programs for the University teachers. Moreover, the University can expand the necessary level of competencies among teachers, required at a given time and in a specific discipline, which creates a condition for improving the educational process of the University.

On the second question of the interview, the majority of respondents (78\%) believe that the best way to develop their pedagogical competencies is to regularly communicate with their mentors - more professionally competent people. They do not believe that using training programs is so important.

If we consider the career growth of a teacher as a dynamic process, then it should be noted that it is directly related to professional growth, as well as the readiness of the individual for self-development and selfimprovement within the framework of his own professional activity. The teacher himself is of fundamental importance in professional growth, as well as his expectations, ideas about his working future.

A comprehensive approach to solving this problem is necessary. We believe that for professional growth and improving pedagogical competencies, it is necessary to create both discussion round tables with university mentors and use various programs to improve qualifications.

On the third question of the interview, the majority of the respondents $(83 \%)$ did not plan to engage in scientific and pedagogical activities in the volume in which they are engaged at a given time, $15 \%$ of the respondents coincided with reality, $2 \%$ found it difficult to answer this question.

We can draw the following conclusion that while studying for a postgraduate program, future teachers are faced with a small amount of work, which concerns both teaching and research activities. As a rule, the "life" of doctoral students themselves does not coincide with the real requirements for teaching and research activities.

Thus, during the training of doctoral students, it is necessary to bring them closer to the real requirements of a scientific and pedagogical career. It is possible to realize these real conditions by increasing the load on pedagogical activity, scientific and publication activity.

On the fourth and fifth question. All respondents indicated only one reason - lack of time and they would like to devote more time to the pedagogical component of their work.

If we want to achieve better results in the scientific component in a pedagogical career, then the results 
obtained must be taken into account when compiling the teaching load along an hourly trajectory for each teacher, that is, the hourly load of the pedagogical component must be reduced. This is possible with an increase in the number of staff members in the structure of the department or the university as a whole. This problem opens up a number of tasks for the leadership of the University and the departments under the jurisdiction of which this University is located. However, all respondents $(100 \%)$ would like to reduce the scientific component in their pedagogical work, leaving it to separate specialized scientific centers.

Also, all respondents $(93 \%)$ would like to pay more attention to the very pedagogical process of teaching students - transferring knowledge, communicating with students or teaching students logical thinking, as well as the formation of high-quality professional competencies in their students. They also noted that an attempt to save time in the process of teaching students forms a "time bomb", which in the future will negatively affect the socio-cultural development of society (94\%).

On the sixth question, the opinion of respondents about the methods of promotion was revealed, which were distributed as follows. On the 1st place is such a factor as "The ability to be in sight of the authorities", on the 2nd - "Getting to know the right people", and only 3 of the interviewed teachers believe that promotion can be obtained if there is professional competence and knowledge. and good work results; On the 4th place "The ability to show initiative and responsibility." On the 5th place - "High working capacity". This arrangement of methods, especially 1 st place, is more likely due to the fact that the current situation in the country gives teachers exactly such an idea of moving up the career ladder.

From the analysis of the motives that made the teachers choose scientific and pedagogical activity, it should be noted that $5 \%$ of the respondents noted the possibility of self-realization, for $60 \%$ - the social usefulness of work, $10 \%$ - the possibility of a creative approach to work, $20 \%$ - the relative stability of the workplace, $5 \%$ useful contacts, acquaintances.

It was interesting for us to analyze the choice of motives based on gender. Women have $10 \%$ more opportunities for self-realization than men, and for women, a creative approach to work is also more important. The paradox of the motive was that for men, labor activity is not an opportunity for "part-time work." In general, we can conclude that the woman is more inclined to analyze.

\section{CONCLUSIONS}

How to answer this question - a scientific or pedagogical career, everyone decides for himself. As a result of the questionnaire survey, it was revealed that teachers would like to engage in scientific activities, but they do not have enough time, but at the same time, in the priority of their activities, they become a pedagogical component - the transfer of knowledge, communication with students or teaching students logical thinking, as well as the formation of high-quality professional competencies of their students. They also noted that an attempt to save time in the process of teaching students forms a "time bomb", which in the future will negatively affect the socio-cultural development of society. And in order to improve the pedagogical component, it is necessary to use not only advanced training programs, but also closer communication with university mentors when organizing the educational process. Although it is impossible to point out the priority path - continuing education programs or closer communication with mentors. Since the development of scientific and pedagogical competencies is possible with an integrated approach. At the same time, advanced training, vocational training, and retraining of scientific and pedagogical personnel are today one of the priority areas in public policy, and also become the "strategic goal of creating an innovative university"

\section{REFERENCE LIST}

1. Legostaeva, V.I., Mudrova, E.B. (2009). Attraction and retention in the University of young teaching staff on the basis of modern technologies for adaptation // Universitetskoe upravlenie: praktika i analiz [University management: practice and analysis], 2 (in Russian).

2. Maralova, E.A. (2013). Methodological development of higher and vocational education teachers // Perspektivy nauki i obrazovaniia [Perspectives of science and education], 5 (in Russian).

3. Pan'kova, N.M. (2013). Mission of the University // Perspektivy nauki i obrazovaniia [Perspectives of science and education], 1 (in Russian).

4. Reznik, S.D., Makarova, S.N., Sazykina O.A., Fomin G.B. (2010). Podgotovka i perepodgotovka 
upravlencheskikh kadrov vysshikh uchebnykh zavedenii. Monografiia [Training and retraining of managerial personnel of higher educational institutions. Monograph]. Penza, PGUAS (in Russian).

5. Nikolaev, D., Chugunov, D. (2012). Podgotovka nauchnykh kadrov vysshei kvalifikatsii v Rossii. Stat. sb [Preparation of the scientific staff of higher qualification in Russia. Statistical Compendium]. Moscow, TsISN (in Russian).

6. Reznik, S.D. (2011). University Teacher: problems and prospects // Vestnik Moskovskogo universiteta. Pedagogicheskoe obrazovanie [Vestnik of Moscow University] 2 (20) (in Russian).

7. Reznik, S.D. (2010). Formation of skills of teaching and managerial corps of Russian universities: experience, problems and methodological support // Alma mater (Vestnik vysshei shkoly) [Alma mater (Journal of higher education)], 6 (in Russian).

8. Reznik, S.D., Vdovina O.A. (2013). Prepodavatel' vuza: tekhnologii i organizatsiia deiatel'nosti [University Lecturer: technology and organization of activities]. Moscow, INFRA-M (in Russian). 